\title{
Habitar el retorno mediante la memoria y la escritura*
}

Fecha de recepción: 21de julio de 2017

Fecha de aprobación: 14 de septiembre de 2017

\section{Resumen}

El presente artículo utiliza la escritura literaria con el fin de evidenciar las formas mediante las cuales, tres poblaciones retornadas en la región de Montes de María, resignifican los lugares de la expulsión forzada para hacerlos habitables a partir de sus prácticas del recuerdo. Parto de la idea de que el retorno de población es un proceso en sí mismo y no el capítulo final del desplazamiento forzado. Acudo al trabajo etnográfico y de recopilación testimonial para expositivamente, de la mano de la escritura literaria y la antropología poética, ensayar una escritura sensible que me permita exponer desde la subjetividad el proceso de retorno de población. Como conclusión, propongo que el diálogo antropología- escritura literaria resulta en una herramienta potente para dar cuenta de diferentes procesos de reconstrucción que realizan las personas afectadas por el conflicto armado en Colombia.

Palabras clave: retorno, habitar, recuerdos, lugares, escritura, antropología poética.

Citar: Garzón, M.A. (julio-diciembre de 2017). Habitar el retorno mediante la memoriay la escritura. La Palabra,(31),243-256. doi: https://doi. org/10.19053/01218530. n31.2017.7271.

\section{María Angélica Garzón}

Docente de la Escuela de Ciencias Sociales de la Universidad Pedagógica y Tecnológica de Colombia. Investigadora del Grupo Interdisciplinario de Investigaciones Arqueológicas e Históricas de la UPTC. Doctora en Ciencias Humanas y Sociales, Universidad Nacional de Colombia.

maria.garzon03@uptc.edu.co

* Artículo de reflexión producto de la tesis doctoral: "Las Tácticas del Habitar. Prácticas de recuerdos y (re)significación de lugares en contextos de retorno de población", presentada para optar al título de Doctora en Ciencias Humanas y Sociales, de la Universidad Nacional de Colombia 


\section{la palabra}

\section{Inhabiting the Return through Memory and Writing}

\section{Abstract}

The present article uses literary writing with the aim of exposing the ways in which three "returning" populations in the region of Montes de María resignify the places from which they were forcefully expelled, making them habitable again through practices of memory. The starting point for this research is the idea that the "return" of a population is a process in itself and not the final chapter of forced displacement. For this purpose I rely on ethnographic work and the compilation of testimonies -aided by creative writing and poetical anthropology- in order to propose an expositive, sensitive form of writing that will allow me to examine the process of return of this population, from a subjective position. As a conclusion, I propose the dialogue between anthropology and creative writing as a powerful tool to investigate different processes of reconstruction engaged in by persons affected by the Colombian armed conflict.

Key words: return, inhabit, memory, places, creative writing, poetical anthropology.

\section{L’expérience du retour grâce à la mémoire et l'écriture.}

\section{Resumé}

cet article utilise l'écriture littéraire à fin de mettre en évidence de quelles manières trois populations qui sont retournées dans la région de Montes de María, redonnent un nouveau sens aux lieux du déplacement forcé pour les rendre habitables à nouveau à partir des pratiques du souvenir (Riaño, 2006). Nous partons de l'idée que le retour d'une population est un procès en soi-même, et non pas le dernier chapitre du déplacement forcé. Nous réalisons un travail ethnographique et de rassemblement de témoignages pour essayer, grâce à une écriture sensible, de la main de la littérature et de l'anthropologie poétique, d'exposer à partir de la subjectivité le processus de retour d'une population. En conclusion, nous proposons le dialogue anthropologie-littérature comme un outil qui rend compte des différents processus de reconstruction vécus par les victimes du conflit en Colombie.

Mots-clés: retour, habiter, souvenirs, lieux, écriture, anthropologie poétique. 


\section{Introducción}

El retorno de población ha sido entendido en Colombia como la medida optima de reparación para poblaciones que se encuentran en situación de desplazamiento forzado. Bajo supuestos que conectan la cultura con los lugares de forma esencialista $y$ lecturas sedentarias que niegan las diferentes trayectorias de las poblaciones, la política de atención a víctimas supone que el retorno es la solución al problema del desplazamiento forzado, su otra cara o su capítulo final (Garzón, 2011; 2017). En diversos recorridos y encuentros que tuve con poblaciones retornadas de la región de Montes de María (Departamentos de Bolívar y Sucre), me encontré con procesos muy distantes a este tipo de definiciones. Más allá de una medida de reparación, el retorno se me presentó como un proceso de habitar un lugar marcado por la violencia y el horror del conflicto armado interno. Me pregunté entonces: ¿Cómo habitar -de nuevo- este lugar? Por medio de los recuerdos, fue la respuesta (Garzón, 2009; 2014).

Así, mi investigación doctoral se encaminó a preguntarse por las relaciones que se tejen entre las prácticas del recordar (Riaño, 2006) y la (re)significación de lugares marcados por la violencia, todo esto en el lugar de la expulsión forzada, un contexto que, cruzado por la aparente "pacificación del país", por los discursos de verdad, justicia y reparación y por estructuras agrarias que siguen debilitando la economía campesina, promete un mejor vivir para las víctimas del desplazamiento forzado. La complejidad de los procesos de retorno rastreados por mí y las apuestas que las poblaciones retornadas de El Salado, Macayepo y San José del Peñón hacían sobre su vida y su territorio, me exigieron construir una plataforma de investigación interdisciplinar en la que no bastó tender puentes entre los estudios de las memorias, la sociología de la vida cotidiana y los estudios de movilidad forzada para dar cuenta de estos procesos.

Recurrí, entonces, a la literatura no solo como estrategia expositiva, sino porque encontré diálogos fructíferos que podían darse entre la antropología poética y la literatura, para explorar los efectos subjetivos de la violencia del conflicto armado, dar cuenta de los procesos de reconstrucción que realizan las víctimas y las tensiones que cruzan el proceso de volver. La literatura se me convirtió en elemento potencializador del discurso antropológico $\mathrm{y}$ sociológico, en fuente de información $\mathrm{y}$ en estrategia de expresión. Siguiendo a Richard (1994), comprendí que:

Rehabilitar esa palabra como campo de fuerzas plurales y divergentes sirve para abrirse a una multiplicidad de puntos de vista cuyas contradicciones no deben permanecer silenciadas por la voluntad de hoy de disolver toda opacidad, de eliminar todo cuerpo extraño que amenace con enturbiar la visión de una historia cultural falsamente reconciliada consigo misma ( $\mathrm{p}$. 18).

El método narrativo que venía utilizando en la investigación, se amplió para dar cabida a formas que me permitieron superar los "moldes canónicos, limitantes y acartonados" (Gómez-Esteban, 2011, p. 96) de la escritura académica para ensayar formas de expresión etnográficas asociadas a formas literarias ${ }^{1}$. Así entendí, siguiendo a Alvarado (citado en Serón, 2010), que los programas científicos en ciencias sociales son también proyectos escriturales. Como socióloga, me interesó acercarme a la escritura literaria, pues encontré en esta escritura la mejor forma de narrar lo que es "evocado y re-vivido con emoción" (Serón, 2010, p. 31). Como señala Blanco (2011),

Expresiones literarias como los diarios íntimos también han dialogado con la investigación social en tanto son expresiones que dan cuenta de una memoria colectiva y que, a la vez, pueden funcionar como dispositivos didácticos. Para una ampliación de este tema, ver González Otero (2017). 
transité de la escritura académica a la literaria para vincular relatos de vida, biografías y autoetnografías, con el fin de expresar sentimientos, emociones y subjetividades que se ponen en juego y se rehacen con el retorno de población.

Mi intención en este artículo es presentar los resultados de mi ensayo. Expongo aquí parte del capítulo cuarto de mi tesis doctoral en el que puse en práctica la escritura literaria como forma de dar cuenta de los profundos procesos de (re)significación de lugares que se dan en el marco del retorno de población y su relación con las prácticas del recuerdo. Para esto, narro una jornada de trabajo etnográfico en un poblado retornado de la costa caribe colombiana. Utilizo esta imagen con el fin de articular en un texto sensible: palabras, imágenes y vivencias, con el fin de transmitir aquello que se manifiesta en las narrativas de las personas retornadas y que usualmente se escapa al lenguaje académico (Blanco, 2011; Gómez-Esteban, 2011). Me interesa, además, hacer uso de la imagen, porque ella, tal y como lo afirma Das (2008), "conceptualiza mejor en el contraste entre decir y mostrar" (p. 160) y porque, según Bachelard (2000), las imágenes "son más imperiosas que las ideas" (p. $84)^{2}$.

\section{La llegada}

Me dirigía a este poblado en compañía de un amigo: Leo. Él, conocedor de la región, me invitó a la casa de una amiga suya para que pudiéramos almorzar antes de emprender nuestro viaje. María, la amiga de Leo, me ofreció para almorzar mote de queso: una sopa espesa hecha con ñame y queso costeño, que a mí me encanta. Comimos, hablamos, nos despedimos y hacia las dos de la tarde emprendimos el camino.

Viajamos aproximadamente veinte minutos y llegamos a nuestro destino. Allí, nos esperaban personas de la región que nos recibieron y nos instalaron. Era la casa de una mujer mayor, una abuela, quien de inmediato nos hizo sentar al lado del fogón y nos ofreció tinto. Su esposo, quien también estaba en la casa, se mostró amable pero menos interesado en nuestra presencia. Cuando el recibimiento se convirtió en charla, inicié con mi labor. Desde que llegué a este municipio, una voz en mi interior me repetía incesantemente: pregunta, vamos, pregunta. Y sí, ya era hora de preguntar.

Se desarrolla la escena.

(En un quiosco tomando tinto después del almuerzo. Le expli- co a la mujer la intención de hacerle unas preguntas, si está de acuerdo y si me quiere contar. Ella, un poco nerviosa, accede. Mi amigo Leo me ayuda con la grabación. Yo trato de concentrarme en las preguntas, es difícil, con el calor que hace me dan muchas ganas de dormir, trato de concentrarme).

—Cuénteme sobre su regreso.

-Yo cuando me vine, me vine fue alegre. Cuando yo me acostaba le decía: mi dios dame vida y salud y me regresas pa' mi casa porque yo mi casa no la voy a dejar caer. Y así que me vine.

- ¿Cómo hizo para regresar? ¿Contrató una moto o cómo hizo?

-Yo me vine fue a pie. A pie solita, salí a las cuatro de la madrugada.

—YY se vino sola, sola?

—Sí, sola, sola, caminando ¡y ese camino sucio! El camino le daba el monte a uno como por aquí (se señala la cintura).

— ¿Recuerda cuánto tiempo caminó?

\footnotetext{
A propósito del mostrar, otro de los resultados de esta investigación, es el documental titulado: "La tierra donde uno vive", realizado con la población de San José del Peñón y disponible en: https://www.youtube.com/watch?v=tBbNcWdTmUs\&$\mathrm{t}=14 \mathrm{~s}$
} 
—Uy, como más de dos horas.

(No pasó mucho tiempo para que el tinto hiciera efecto en mí. Bueno, no sé si fue el tinto o lo interesante de la narración, pero el sueño se me fue y pude concentrarme totalmente en lo que la mujer me contaba. ¡Que emoción poder hablar con esta mujer. Una de las primeras en llegar, una lideresa del retorno!).

-Vino el gobernador como con cinco carros llenos de personal. Pero él vino en helicóptero, el gobernador. $\mathrm{Y}$ cuando se bajó, preguntó: ¿Cuál fue la primera mujer en regresar? Y yo levante la mano y dije: Yo. Y entonces, me abrazó. No me quería soltar (risas). Después, paseó por todas partes, $\mathrm{pa}^{\prime}$ ya y pa' ca. Después el gobernador no volvió ni mandó nada. Por ahí mandaron unos mercados, como tres, pero no sé quién nos mandaba eso. No nos dieron más nada porque dicen que no somos desplazados y ajá uno pobre. Eso es para que nos estuvieran dando cualquiera cosa, para ayudar con la comida, pero nadie.

(Mientras escucho, pienso, pienso y pienso... se me va a reventar la cabeza de tanto pensar: a la violencia ejercida por grupos paramilitares y guerrilleros se le suma la violencia ejercida por un Estado que históricamente ha estado ausente y que ahora se presenta con una serie de "promesas" de reparación, que todavía no cumple a cabalidad: carreteras intransitables, falta de acueductos y alcantarillados, escuelas en precarias condiciones, los campesinos sin acceso a tierra propia; en general, unas condiciones que no evitan o previenen la repetición de los hechos de violencia que produjeron el desplazamiento forzado).

- Vamos allá a la alcaldía a decirle al alcalde qué necesidad tenemos aquí, pero él no nos oye, no nos oye. $¿ \mathrm{Y}$ a que vamos a ir otra vez? ¿A gastar la plata de los pasajes? No señor, ya uno no puede estar. Son días que uno se gasta, el ir y venir, el alcalde no nos lo va a pagar. Dicen que uno le tiene rabia al alcalde, pero no, uno tiene que decir la verdad, eso es que uno no va a humillar el alcalde sino que él tiene que hacer por nosotros, porque nosotros valemos más porque somos retornados.

(Estaba tan interesada en las palabras de la mujer, que no sentí la otra presencia. Una voz fuerte me sacó del trance para ubicarme ante la imagen de un hombre triste. Muy triste. El esposo de la mujer había estado allí por un buen rato escuchan- do nuestra conversación. Seguramente, intentó hablar una y otra vez, pero las palabras se le refundían. Finalmente, sacó fuerza y dijo:).

-Yo cuando regresé, ¡Uyyyy! Yo me metí en el baño, ese de allá y lloré viendo como estaba destruyéndose, el patio sin un animalito ni nada, las calles sucias, una tristeza... la tristeza que me dio de llegar al pueblo y verlo tan destruido, la tristeza que se veía en el mismo pueblo. La gente casi no salía.

(Como señala Flor Edilma Osorio: la guerra genera procesos contundentes, destructivos, arrasadores, dolorosos, profundos, abruptos e intempestivos en la vida de los sujetos individuales y colectivos, en sus memorias e historias [2009, p. 6]. Como respondiendo a su marido entra la voz de la mujer)

-Yo quedé limpia fue con el desplazamiento, nos fue mal. Yo lloraba. Yo decía dios mío ponme en mi casita, yo no quiero estar aquí en este pueblo, yo me estoy acabando en vida.

(La mujer sigue...)

—Esa vida fue mala, no me gustó. Y me dije, nombe, esa vida no es para mí, entonces me regresé con tres de mis hijos. 
Artículo 73. Principios de la restitución. Participación. La planificación y gestión del retorno o reubicación y de la reintegración a la comunidad contará con la plena participación de las víctimas (Ley 1448 de 2011, en red, p. 37).
- ¿Y cómo encontró el pueblo?

El pueblo estaba maluco, maluco y triste. Yo decía qué carambas, yo voy a limpiar y me iba para las calles a limpiar. Yo no es- taba triste, estaba era feliz porque regresé. Es que yo tengo sesenta y tres años de estar aquí. Yo soy feliz, uno aquí no pasa necesidad porque uno trabaja, por eso crio gallinas y puercos.

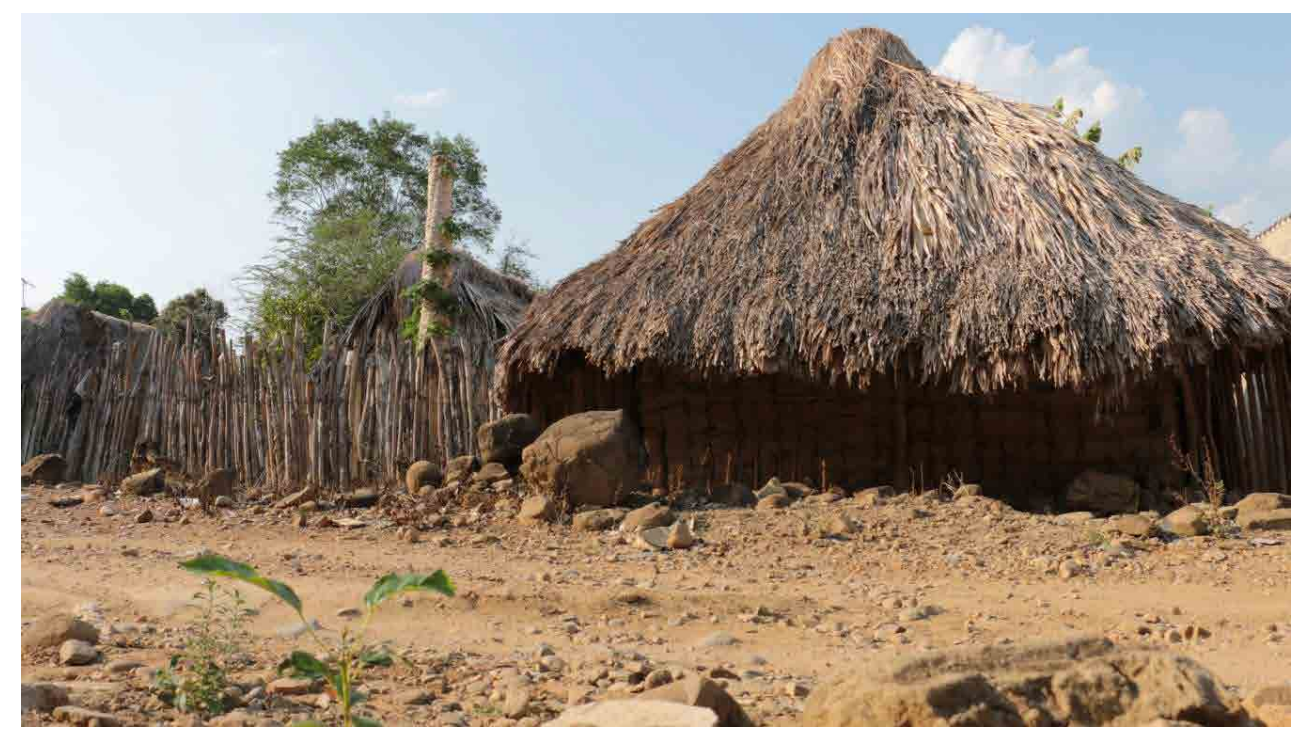

(Miro al esposo, quiero saber su versión. Me da una percepción distinta frente al desplazamiento forzado y contradice a la esposa. Me dice que a ellos no les fue mal. Que vivieron en la casa de un familiar sin pagar arriendo. Que subsistían gracias a una tiendecita que colocaron y que además se ayudaban económicamente con la venta de suero que ellos mismos producían).

- ¿Por qué retorno? Pregunto sorprendida.

(El esposo se ríe y me contesta)
-Porque la señora mía venía semanalmente a la casa. Todos los viernes por la tarde. Hasta que se quedó. Después yo me regresé. Ya después se compuso la cosa, ya no había esa tristeza, ya había cambiado el pueblo.

\section{El recorrido}

Como visitante, me interesaba conocer el pueblo. Mi anfitriona, una campesina que dejaba ver en su rostro envejecido -a pesar de su juventud- las mar- cas de una vida difícil y luchada, se entusiasmó con la idea:

- ¿A dónde quiere ir? Me preguntó.

--A dónde usted disponga, le dije.

Iniciamos el recorrido en su casa. Me mostró su habitación, la habitación de sus hijos y el cuadro que había dibujado en un taller de apoyo psico-social: una flor renaciendo como lo era ella misma, me explicó. 


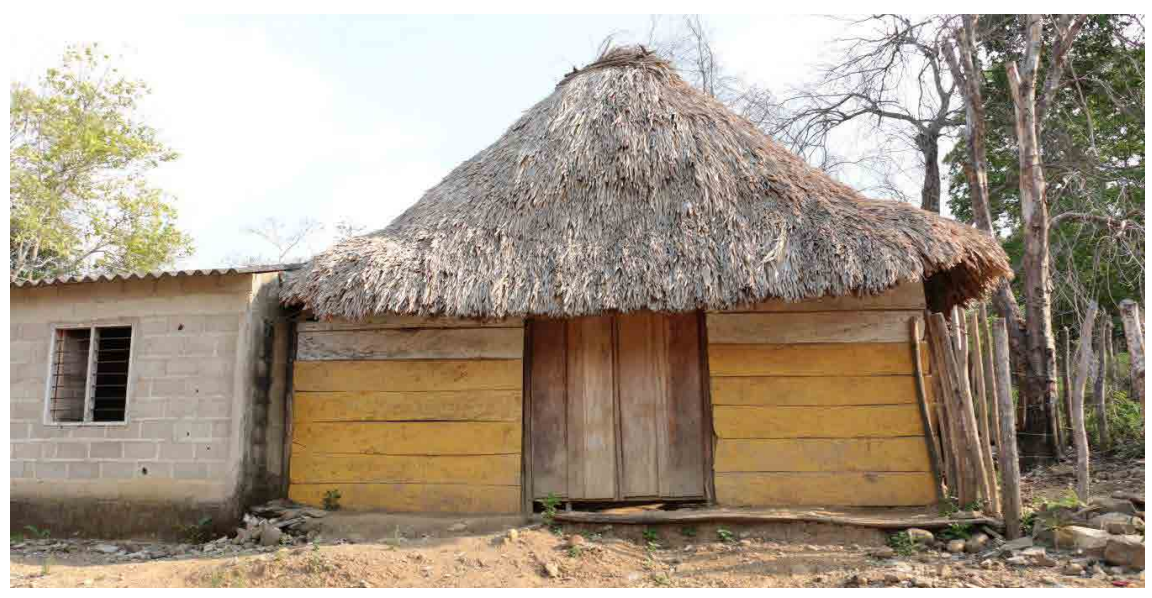

Seguimos con el recorrido. De casa en casa, de calle en calle. La vida ya no era la misma. ¿Y cómo podía serlo? Del pueblo que en otras épocas había sido una despensa agrícola y un destacado productor de tabaco, había quedado muy poco.

-Yo trabajaba aquí, dijo mi anfitriona. Doblaba el tabaco en esta bodega. ¿Quiere entrar?

-Claro, nunca he visto una fábrica de tabaco.
El edificio era grande, de una sola planta, con algunas ventanas y ninguna puerta que sirviera. Entrar fue fácil, caminar sobre los escombros, difícil.

-Poco tabaco se produce ahora. Me dijo.

- Claro, con lo del desplazamiento y demás, comenté yo.

-La mujer me corrigió: no. Es por las tierras, no hay donde sembrar.
De nuevo el silencio entre las dos. Mentalmente me reproché. Durante el recorrido por la bodega había estado más pendiente de no tropezar o lastimarme con algún vidrio roto, que de escuchar el relato de la mujer. Su vida, su trabajo, sus expectativas, habían quedado atrás. Su vida, su trabajo, sus expectativas, ahora hacían parte de aquellos escombros que yo intentaba evadir. Su vida, su trabajo, sus expectativas, dejaron de ser suyas. La vida ya no era la misma. ¿Y cómo podía serlo?

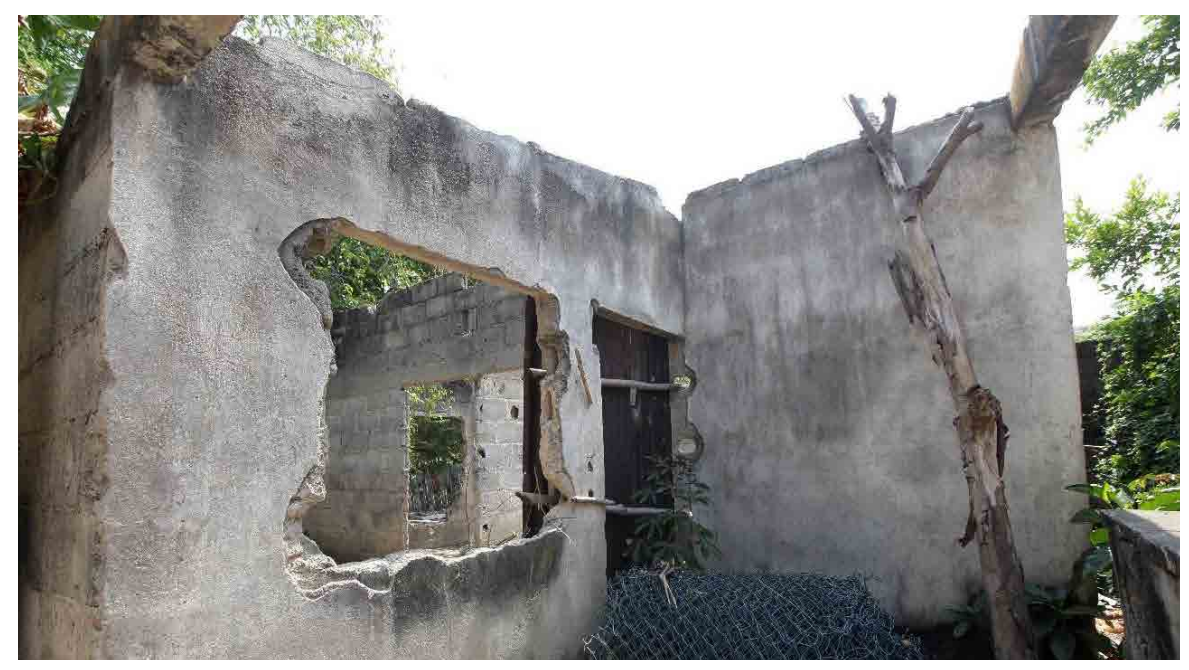


Seguimos caminando. Finalmente, llegamos a la plaza, frente a la iglesia. Allí un juego para niños que se notaba recién instalado. Ella recordó:

- Nos reunieron a todos aquí en la plaza. Pero no se metieron con uno. Solo nos dijeron que el que se sintiera culpable que se fuera. Al día siguiente, todo el mundo estaba alistando los mulengues para irse. Montando todo en burro para irse. Yo, cuando vi salir toda la gente, dije: yo también me voy. Nos fuimos toditos juntos.

- — ¿Y después de un tiempo retornaste? -le pregunté.

一Sí.

Un sí a secas, sin nada más que añadir, solamente sí respondió ella. Esperaba que me comentara de su retorno, de las razones para volver, del cómo volver y hacer realizable este proyecto. Esperaba que respondiera a todas mis preguntas a través de sus palabras. Ella solo respondió: sí.

\section{Cuerpos, sabores y objetos del retorno}

Todo en el retorno permite la evocación de recuerdos. Desde las acciones hasta los objetos. Habitaciones, corredores, ropa, música, comida, gallinas y demás. Todo se encuentra investido de memorias: "a los retornados algunos les dieron un carrito para traer las cosas de allá, pa' regresarse. Yo me traje todo de allá: un enfriador, una cama grande, la nevera, los chismes. El abanico ese (con la mirada señala el aparato), también me lo traje de allá" (Testimonio hombre retornado).

(A propósito de las pérdidas)

Eso es muy duro, se pierde la mayoría de las cosas o las vende mal vendidas o venía gente a cogerse las cosas de uno. Tenía la señora una maquinita vieja de esas de pie y se la llevaron (Relato hombre retornado).

(Nota diario de campo: esta abuela me recuerda a la mía, terca, testaruda, sabia con sus manos. Me sentí en confianza y me atreví a preguntarle por los postres: $i^{-}$ cómo es que se prepara los postres? Ella, amablemente, se decidió a regalarme sus recetas).

Preparación dulce de papaya:

- Se toma una papaya que ya esté bonita y se le pela. Toca sacarle solo la cascarita, la pulpa no porque esa es la que se cocina.

Cuando la papaya ya está pelá, se le corta en pedacitos.
Se pone una olla a hervir y se le echa la papaya para que cocine y suelte el aroma

Toca dejarla al fuego hasta que se cocine.

Cuando ya está cogiendo forma, se le echa la panela, coco y clavitos

Se comienza a revolver hasta que dé el punto.

Ella misma va dando el punto, es cuando se pone negrita.

De ahí, se saca y se deja enfriar

Ya está.

Dulce de Güandul:

-Al güandul toca cocinarlo primero porque ese es duro, cocinarlo para que ablande.

Cuando ya está blandito se le saca de la olla, se deja enfriar y ahí si se muele.

Después lo molido se cuela para sacarle el bagazo.

A lo que queda, se le echa azúcar y leche. No mucho porque o sino no espesa. 
Eso se pone al fogón a que cocine y dé el punto.

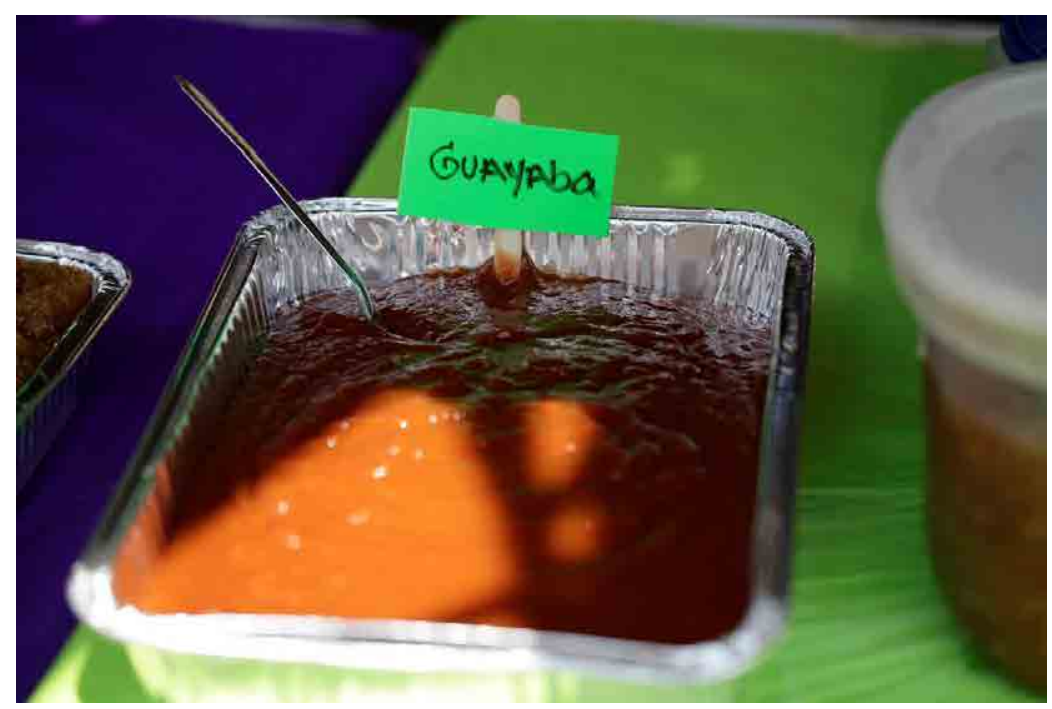

El contexto:

Presentación del grupo de baile de niños y niñas del municipio.

El recuerdo:

(La mujer ve a sus nietas bailar, piensa, se ríe, me cuenta....)

—Yo bailaba gaita con el difunto, con Freddy Dionisio. Me traían una caja de espermas y se las quemaba en dos noches. Pero yo era mala, yo la cogía para quemarle los güevos (risas)...!uy! Yo les hacía más maldad (risas).

Estos testimonios me recuerdan a Osorio (2009) cuando habla

Cuando está espeso, ahí ya se retira del fogón y ya está.

\section{El lugar biográfico}

En el retorno las huellas de la violencia, se presentan inscritas tanto en el espacio físico como en la historia personal. Entonces, el retorno implica no solo la (re)significación de lugares sino también de biografías. De esta forma, el espacio físico se transforma en espacio biográfi-

\section{Dulce, cocina y embarazos}

Después de regalarme sus recetas, la abuela insistía en que yo comiera la gran variedad de postres que había preparado. ¡No puedo con tanto! Le dije sonriendo. Ella, de forma firme, me dijo: eso no le va a disgustar el estómago, tome, cómaselo. Entonces, le expliqué que yo estaba recién parida y que, con el embarazo, el gusto por el dulce se me había ido. La hija de la abuela, una mujer joven, quien estaba en la cocina terminando otros postres, me escuchó y me contó sobre su embarazo.

(En la cocina, junto al fogón de leña, tres mujeres: la abuela sentada en una silla de madera, la hija de la abuela batiendo el melao hasta que diera el punto y María Angélica tratando de terminar el tercer postre que se comía "obligada" por la abuela durante la tarde).
-Mujer joven: cuando eso sucedió yo estaba embarazada, pero no sabía. Me vine a dar cuenta porque en el camino me dio la pálida, si sabes, lo que aquí decimos lo del piñi; me dio el piñi y tocó que me llevaran en un burro. Yo pensé que la niña iba a salir mal, más loca, como 


\section{la palabra}

dicen por aquí: más desatornillada.

(Las mujeres jóvenes se ríen, la abuela se encuentra pensativa... continúa el relato).

-Mujer joven: pero no, afortunadamente no. Es que con ese caso hay niños aquí, que uno no dice que son malos ni nada de eso, sino que ellos sufrieron la violencia aquí y son unos poquitos que son desordenados. No es que uno diga que son malos, no es que sea malo el pelao, sino que es, es [...] por los sustos que a uno le sucedieron aquí.
-María Angélica: ¿y te sucedieron sustos a ti?

-Mujer joven: yo tuve sustos porque ellos (grupo paramilitar) fueron allá donde yo vivía y se pararon a decirme: niña una reunioncita, no te vamos a hacer nada. Yo me asusté. Yo les dije: yo no puedo ir porque yo estoy quizá embarazada y no sé qué es lo que tengo, porque yo tenía una maluquera. Yo supe lo del embarazo cuando ya llegué a donde nos desplazaron [...] fue verdad que yo estaba embarazada. Tenía dos meses. Yo pensé que la niña mía me iba a nacer loca, pero gracias a dios no nació mal.

-María Angélica: es cuando se ven los efectos de la violencia.

-Mujer joven: sí. Sí. Mira, cuando nos desplazaron resultaron muchos niños perdidos en las drogas y yo le dije al hijo mío: no hagas eso porque eso es malo. Mujeres que buscaron novios, que salieron embarazadas de 14 años y yo le advierto a la hija mía: mire niña usted no haga eso nunca.

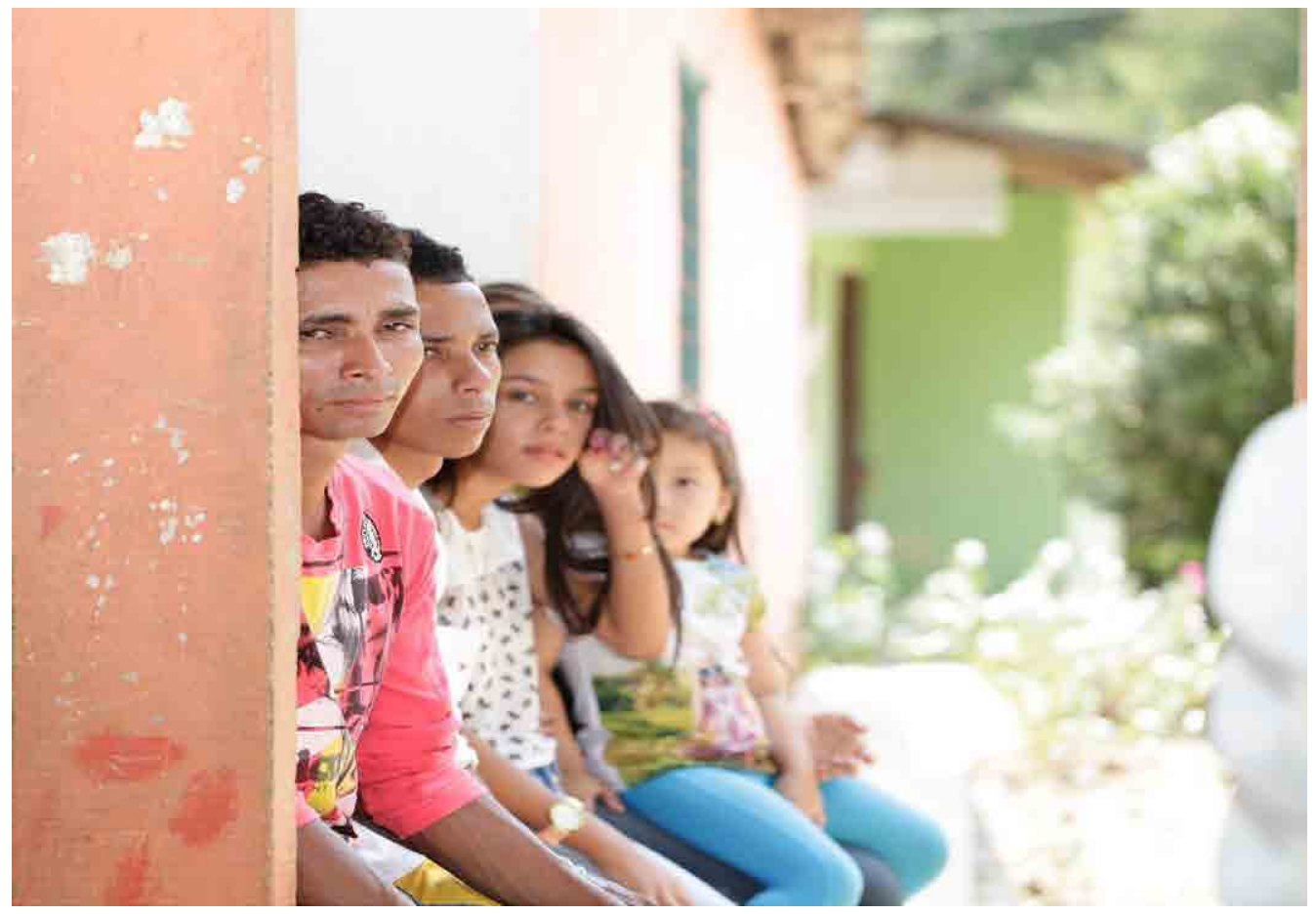




\section{De la noche y sus recuerdos}

Retornar no es solo volver, es reconstruir la vida y la historia personal.

(En la calle, sentadas en el bordillo, tomándonos una cerveza. Son las seis de la tarde, la oscuridad comienza a cubrir el poblado).

—Cuando regresé me daba miedo la oscuridad, dijo ella. Tenía miedo de que iba a volver a pasar. Cuando llegaba la noche, ¡uy!, la pasaba mal.

- ¿Y sigues teniendo miedo? Pregunté.

—Ya no, me contestó. Ya salgo en la noche y todo. Uno se va acostumbrando a estar aquí, aunque al principio, ¡uy! No.

Caminando lento llega el amigo al que estábamos esperando. Pide una cerveza y se sienta a nuestro lado. Le comento que hablamos de la noche y el miedo: ¿tuviste miedo de volver?

- ¿Qué si miedo? Una terronera (risas). Es que... (pensando). Silencio.
Mueve su cabeza, mira el horizonte, toma aire y me dice:

-Yo veía los manchones de sangre, me imaginaba a los muertos, pero ya no veo eso. (Suspirando dice) Pa'lante, pa'lante es pa'1la.

\section{La despedida}

Obligada, terminé el tercer dulce de la tarde. Con gusto de saciar la sed, terminé la cerveza. Con mil sentimientos encontrados, terminé las conversaciones y entrevista (Richard, 1994). Me despedí de la gente del poblado.

El proceso de (re)significar los lugares en el marco del retorno, no es un proceso fácil, armónico o lineal. Con la guerra, las huellas de la violencia se inscribieron tan fuertemente en geografías, paisajes, estructuras $\mathrm{y}$ vidas, que reescribirlas resulta casi imposible. Por ello, las calles, portales de casas, iglesias, parques y plazas, siguen recordando la escenificación y vivencia del conflicto interno: reuniones forzadas, filas de hombres y mujeres esperando ser asesinados, cadáveres sin entierros y manchas de sangre son algunos de los recuerdos asociados a estos lugares. A lo anterior, se suma la presencia de ruinas, escombros, de las calles "sucias". La presencia de todo aquello que recuerda el paso del tiempo y el abandono.

Entonces, en los pueblos retornados todavía predominan las “imágenes de horror y destrucción” (Riaño, 2006, p. 51) legados por el conflicto armado. Imágenes que también hacen parte de los lugares biográficos que desestructurados por la violencia, re-estructurados por la experiencia del exilio y confrontados con el volver deben rehacerse para poder habitar y habitarse en ellos. De esta forma, en el retorno convergen múltiples procesos de (re)significación de lugares que hacen posible el volver, quedarse y planear futuros mejores: "Que me ayuden tan siquiera a componer la casa" (Testimonio mujer retornada).

Con la despedida, ellos y ellas tomaron su camino y yo tomé el mío. También voy de regreso. En mi cabeza todavía resuenan los rostros, las historias y las palabras que durante la despedida me dijo el hombre de mirada triste: "uno no olvida seño, pero uno tiene momentos que ya olvida (silencio)... la vida continúa". 


\section{la palabra}

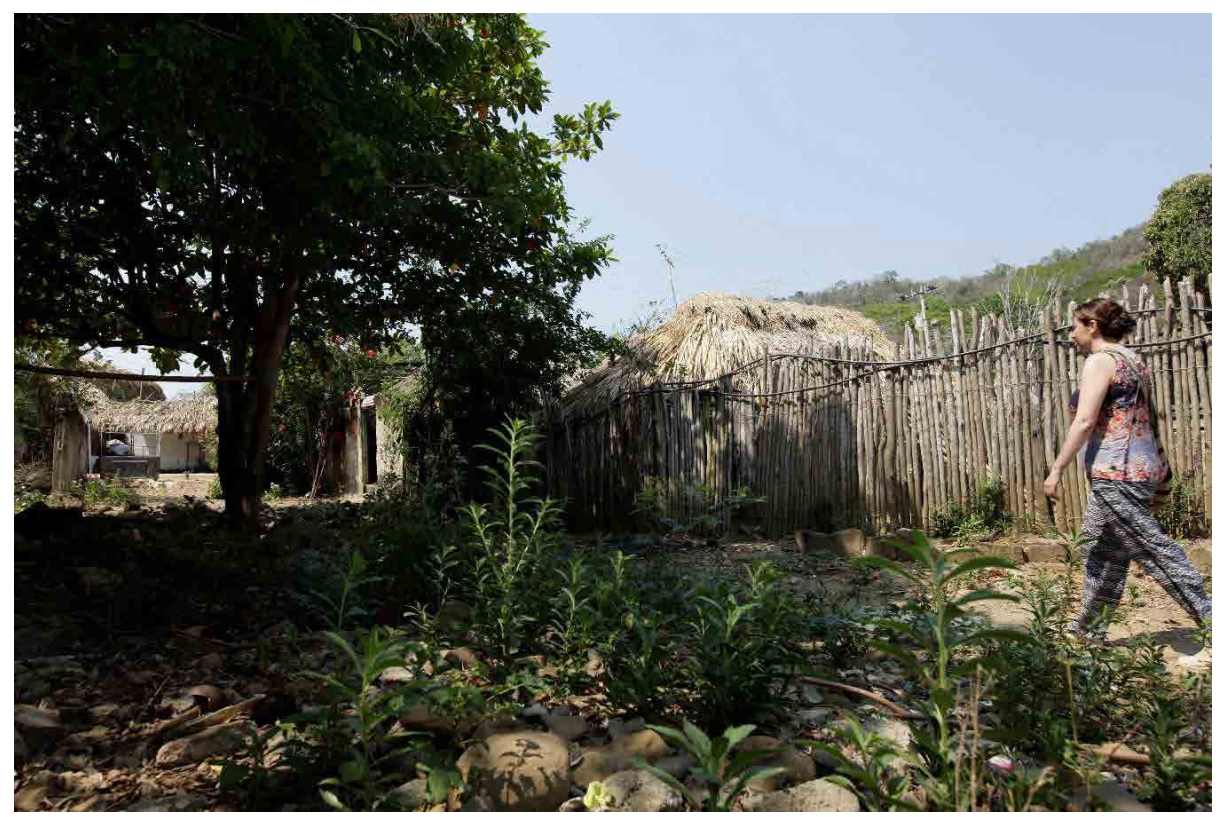

3. Habitar mediante la escritura

Denunciar la violencia del conflicto armado en Colombia y los efectos que esta tuvo en poblaciones, subjetividades, espacios y proyectos de vida, es un trabajo que sigue siendo pertinente $y$ necesario. Para esto, propongo diálogos interdisciplinares que asuman la literatura no solo como fuente anecdótica de información, sino que la ubiquen en un lugar central dejándose permear por sus posibilidades y abriéndose al campo creativo que ella propone. En este caso, el diálogo entre antropología poética y literatura resultó no solo en elemento de exposición escritural, sino que me permitió acercarme desde otras perspectivas a la realidad del retorno para complejizarla y estudiarla desde diferentes aristas; abrien- do de esta forma el campo a posibilidades teóricas, creativas y políticas desde el juego de saberes que plantea la interdisciplinariedad (Brijaldo, 2014).

La literatura, como bien lo señala Adichi (2009), es un escenario de indagación potente que permite romper el molde de la historia única, y con ello dignificar a las poblaciones. En términos de las poblaciones retornadas de los Montes de María, la literatura me permitió mostrarlas como seres humanos que han sufrido por la victimización del desplazamiento forzado, pero que también han logrado rehacerse mediante el retorno. Mostrar el matiz humano de estos procesos a partir de la sensibilidad, la emoción y la cotidianidad, es un procedimiento que, apuestas como la mía, permiten realizar. Enunciar un mejor futuro posible y permitirse soñar con él, es otra de las posibilidades que brinda la literatura como herramienta de investigación social.

En términos de reconstrucción de memoria, como ya lo plantea Richard (1994), la literatura resulta en un dispositivo privilegiado para la disputa de significados en torno al pasado. Así, las luchas políticas frente a la reconstrucción de memorias de violencia y exclusión y las voces llamadas a reconstruirlas comienzan a integrar la traza o la gramática de la significación como elemento estructurante de la confrontación. De esta forma se plantean escenarios en los que la palabra, la significación y la reclamación de una voz propia tienen importancia. Para el caso de las poblaciones retornadas con las que trabajé, 
ser escuchadas, encontrar que sus testimonios tienen valor y que pueden ser traducidos como reclamos políticos resultó fundamental para empoderar en términos de ciudadanía.

\section{Referencias}

Adichi, C. (2009). El peligro de una sola historia. Recuperado de http://www.ted.com/talks/lang/es/ chimamanda_adichie_the_danger_of_a_single_story.html

Bachelard, G. (2000). La poética del Espacio. México: Fondo de Cultura Económica.

Blanco, M. (2011). Investigación narrativa: una forma de generación de conocimiento. NUevA ÉpocA, 24(67), 136-156.

Das, V. (2008). Trauma y Testimonio. En F. Ortega, Venna Das: Sujetos de dolor, agentes de dignidad (pp. 145-169). Bogotá: Editoriales CES.

Feldman, A. (1994). From desert storm to Rodney King via ex-Yugoslavia: On cultural anaesthesia. En N. Serematakis, The Sense Still: percepcion and memory as material culture in modernity (pp. 87-109). Chicago: The University of Chicago Press.

Garzón, M. A. (2009). Recordando vidas, imaginando territorios. Revista Virajes, 11.

Garzón, M. A. (2011). Ampliando el campo. Estado de la cuestión de la literatura dedicada al tema del retorno de población en situación de desplazamiento. Boletín de Antropología, 25(42), 11-35.

Garzón, M. A. (2014). Las narrativas del retorno. Encuentros. Universidad Autónoma del Caribe, 12(2), $67-77$.

Garzón, M. A. (2017). Tácticas del Habitar. Prácticas de recuerdo y (re)significación de lugares en contextos de retorno de población. (Tesis doctoral). Universidad Nacional de Colombia, Bogotá, Colombia.

Geertz, C. (1989). El antropólogo como autor. México: Paidós.

Gómez Esteban, J. H. (2011). Del hecho al dicho hay poético trecho. Prolegómenos para una investigación social literaria. Magis, Revista Internacional de Investigación en Educación, 4(7), 87-103.

Haraway, D. (1991). Simians, Cyborgs and Women: The Reinvention of Nature. Londres: Free Association Books. 
Oslender, U. (2006). Des-territorialización y desplazamiento forzado en el Pacífico colombiano: la construcción de "geografías del terror". En D. Herrera \& C. Piazzini, (Des) territorialidades y (No) lugares. Procesos de configuración y transformación social del espacio (pp. 155-173). Medellín: La Carreta Editores.

Riaño, P. (2006). Jóvenes, memoria y violencia en Medellín. Una antropología del recuerdo y el olvido. Medellín: Editorial Universidad de Antioquia / ICAHN.

Richard, N. (1994). La insubordinación de los signos. Santiago: Un cuarto propio.

Richardson, L. (2003). Writting. A method to inquiry. En Dezin \& Lincoln, Collecting and Interpreting qualitative Materials. California: Thousand Oaks.

Serón, M. (2010). Cuestiones y controversias en antropología poética y antropología literaria chilenas. Sociedad Hoy, 18, 27-39.

The Personal Narratives Group. (1989). Interpreting Women's Lives. Feminist Theory and Personal Narratives. Indiana: Indiana University Press. 